\section{Agriculture development-based mapping of agro-ecological sub-regions and its implications for doubling farmers' income in India}

\author{
S. K. Srivastava ${ }^{1, *}$, N. P. Singh ${ }^{2}$, Jaspal Singh ${ }^{1}$, \\ K. V. Rao ${ }^{3}$ and S. J. Balaji ${ }^{2}$ \\ ${ }^{1}$ National Institution for Transforming India (NITI Aayog), \\ New Delhi 110 001, India \\ ${ }^{2}$ ICAR-National Institute of Agricultural Economics and Policy \\ Research, New Delhi 110 012, India \\ ${ }^{3}$ ICAR-Central Research Institute for Dryland Agriculture, \\ Hyderabad 500 059, India
}

Prioritizing and targeting less developed regions is one of the multi-pronged strategies for doubling farmers' income (DFI) in India. Using an indicator approach, the present study assessed and mapped agro-ecological sub-regions (AESRs) based on ten indicators representing production, infrastructure, information, marketing and income of the farmers. On the basis of the composite index of agriculture development, AESR 9.1 and AESR 1.1 were found to be the most and the least developed regions respectively. Further, the potential districts for each of the less-developed AESRs have been identified for greater prudency in planning. The study concludes that for achieving the target of DFI within the stipulated time-frame, it is imperative to mainstream AESR-based planning in technological development and dissemination. The evidences revealed large and equitable response of the efforts targeted towards less-developed regions.

Keywords: Agro-ecological sub-regions, agricultural development, characterization and mapping, doubling farmers' income.

THE target of doubling farmers' income (DFI) by the year 2022 departs from the earlier agriculture development strategies, with a greater focus on improving the prospects of farmers' income in addition to output growth. Multi-pronged strategies and action plans are adopted to accomplish this target ${ }^{1,2}$. One major segment of such an overreaching framework involves accelerating investment and developmental activities in agriculturally less-developed regions to address spatial disparity and growing livelihood shocks. However, assessment of agriculturally less-developed regions is a prelude for implementing technological and policy interventions.

Unlike industry, performance of an agriculture system relies on the complex interactions among climatic, ecological and socio-economic factors. In order to utilize available limited resources effectively and develop locationspecific technologies, several agencies and scholars have

\footnotetext{
*For correspondence. (e-mail: shivendraiari@gmail.com)
}

delineated and characterized homogenous regions based on soil, climate, physiography, etc. ${ }^{3-7}$. The basic purpose of delineating such regions is to identify a homogenous land unit, which will behave similarly under a given set of management practices imposed on a particular land use ${ }^{8}$.

In spite of delineation of agro-ecological zones (AERs) at various levels of refinement, their use in planning has not been to the desired level ${ }^{9}$. Further, studies on the assessment of agro-ecological regions (AERs) or agroecological sub-regions (AESRs) based on agricultural development are limited. This study maps and ranks different AESRs of the National Bureau of Soil Survey and Land Use Planning (ICAR-NBSS\&LUP, Nagpur) with the selected indicators of agricultural development. Moreover, the study also delineates relatively homogenous regions, explores intra-AESR variations in the level of agricultural development, and draws implications of mapping AESRs for achieving the target of DFI.

ICAR-NBSS\&LUP has delineated 20 AERs based on length of growing period as an integrated criterion of effective rainfall and soil groups with boundaries adjusted to district level. Later, these 20 AERs were subdivided into 60 AESRs. In the present study, agricultural development in AESRs was assessed in terms of ten indicators representing production, infrastructure, information, marketing and income of farmers. The district boundaries were superimposed over the AESR map and contribution of each district area to every AESR was worked out. In the absence of information on development indicators chosen at sub-district level, the indicator was assumed to be uniformly representing the entire district. Table 1 presents description of indicators under consideration. The mean values of these indicators were estimated for the period 2011-13 at district level and further aggregated at AESR level using district area under each AESR as weight. The agricultural development was assessed for all AESRs, except AESR-20.1 and AESR20.2 (covering Andaman and Nicobar Islands) due to unavailability of data.

AESRs were characterized in terms of selected indicators and a composite index of agricultural development (ADI) was constructed for each AESR using the following statistical procedure ${ }^{10}$.

Let $[X]_{i j}$ be the data matrix, where $i=1,2, \ldots, n$ (number of AESRs) and $j=1,2, \ldots, k$ (number of indicators). Since data in $[X]_{i j}$ come from different population distributions and might be recorded in different units of measurement, they are not suitable for simple addition to obtain the composite index. Therefore, $[X]_{i j}$ was transformed to $[Z]_{i j}$ as follows

$$
\left[Z_{i j}\right]=\frac{X_{i j}-\bar{X}_{j}}{S_{j}},
$$

where $\bar{X}_{j}$ is the mean of the $j$ th indicator and $S_{j}$ is the standard deviation of the $j$ th indicator. 


\section{RESEARCH COMMUNICATIONS}

Table 1. Selected indicators of agricultural development

\begin{tabular}{|c|c|c|}
\hline Indicator & Estimation formula (unit) & Data source \\
\hline Farmer income & $\begin{array}{l}\text { Rupees/household/annum (income from crop, livestock, } \\
\text { wages and non-farm activities) }\end{array}$ & $\begin{array}{l}\text { Situation Assessment Survey, } 2012-13 \text { of the } \\
\text { National Sample Survey Office (NSS-SAS) }\end{array}$ \\
\hline Crop output/ha & Aggregated crop output (Rs)/ha & NSS-SAS \\
\hline $\begin{array}{l}\text { Crop output/agricultural } \\
\text { worker }\end{array}$ & Crop output (Rs)/agricultural worker & NSS-SAS and population census \\
\hline Cropping intensity & Gross sown area/net sown area $\times 100$ & $\begin{array}{l}\text { Directorate of Economics and Statistics, } \\
\text { Ministry of Agriculture and Farmers' Welfare } \\
\text { (DEA-MAFW), Government of India (GoI) }\end{array}$ \\
\hline Irrigation coverage & Net irrigated area/net sown area $\times 100$ & DEA-MAFW, GoI \\
\hline Groundwater development & Groundwater draft/groundwater availability $\times 100$ & Central Groundwater Board (CGWB) \\
\hline Fertilizer use & Kilogram/ha & DEA-MAFW, GoI \\
\hline Credit use & Credit disbursed (Rs)/ha & $\begin{array}{l}\text { Centre for Monitoring Indian Economy (CMIE), } \\
\text { Mumbai and DEA-MAFW, GoI }\end{array}$ \\
\hline Access to technical advice & $\begin{array}{l}\text { Percentage of farmers who availed technical guidance } \\
\text { from any of the agencies such as extension department, } \\
\text { Krishi Vigyan Kendra, Agricultural universities } \\
\text { and private commercial agents. }\end{array}$ & NSS-SAS \\
\hline Marketed surplus & $\begin{array}{l}\text { (Value of crop output sold/value of crop output } \\
\text { produced) } \times 100\end{array}$ & NSS-SAS \\
\hline
\end{tabular}

From $[Z]_{i j}$, the best value of each indicator $\left(Z_{o j}\right)$ was identified. As each of the selected indicators bears a direct association with the level of development, maximum value among the AESRs was taken as the best value of the respective indicator. Subsequently, pattern of development $\left(C_{\mathrm{i}}\right)$ of the $i$ th AESR was estimated as follows

$$
\begin{aligned}
& P_{i j}=\left(Z_{i j}-Z_{o j}\right)^{2}, \\
& C_{i}=\left[\sum_{j=1}^{k} P_{i j} /(C V)_{j}\right]^{1 / 2},
\end{aligned}
$$

where $(\mathrm{CV})_{j}$ is the coefficient of variation of the $j$ th indicator in $X_{i j}$.

Composite index $D_{i}$ is given by

$D_{i}=C_{i} / C, \quad$ for $i=1,2, \ldots, n$,

where $C=\bar{C}+3 S_{i}, \quad \bar{C}$ is the mean of $C_{i}$ and $S_{i}$ is the standard deviation of $C_{i}$.

Smaller value of $D_{i}$ indicates high level of development and higher value of $D_{i}$ indicates low level of development. Accordingly, AESRs were ranked in ascending order of the level of agricultural development. Further, AESRs were classified into four groups based on estimated quartile values of the index; AESRs falling in the top quartile class were identified as less-developed regions. The implications of mapping AESRs for DFI were drawn by estimating marginal effects of targeting a given homogenous region (in terms of agricultural development) on overall farmers' income in the nation and inter-regional disparity.

AESRs have been characterized based on each of the selected indicators of agricultural development. For bre- vity, AESR-wise estimated mean values and thematic maps of these indicators are given under Supplementary material. The results show wide inter-AESR variation in the level of indicators, which is expected because of inherent potential and constraints of different AESRs due to heterogeneous soil, climate, physiography, moisture availability, etc. Nevertheless, such characterization reveals the relative position of different AESRs and distinguishes regions with varying levels of agricultural development. The overall level of agricultural development is revealed by the composite index of the selected indicators (ADI).

Figure 1 presents ranking of AESRs based on ADI. AESR 9.1 occupies the first position with ADI value of 0.421, whereas AESR 1.1 is found to be agriculturally the least-developed region with ADI value of 0.920 . The most-developed AESR 9.1 (Northern Plain: hot subhumid dry zone covering parts of Jammu and Kashmir, Haryana, Punjab, Uttarakhand and Uttar Pradesh) is followed by AESR 14.5 and AESR 4.1. On the other hand, the least-developed AESR 1.1 (Western Himalaya: cold arid zone) is preceded by AESR 16.2 and AESR 18.1.

The regions exhibiting nearly the same level of agricultural development were identified by categorizing AESRs into four quartile classes of ADI. These regions are termed as high, moderate, medium and less developed regions with mean ADI values 0.602, 0.689, 0.744, and 0.830 respectively (Figure 2 and Table 2). Table 2 lists AESRs falling into different categories of agricultural development along with the mean values of indicators. As expected, AESRs grouped as highly developed regions exhibited significantly higher values of all the indicators compared to less-developed AESRs. Based on the results, it can be inferred that increasing output per unit of land and strengthening farm-market linkages (through market 


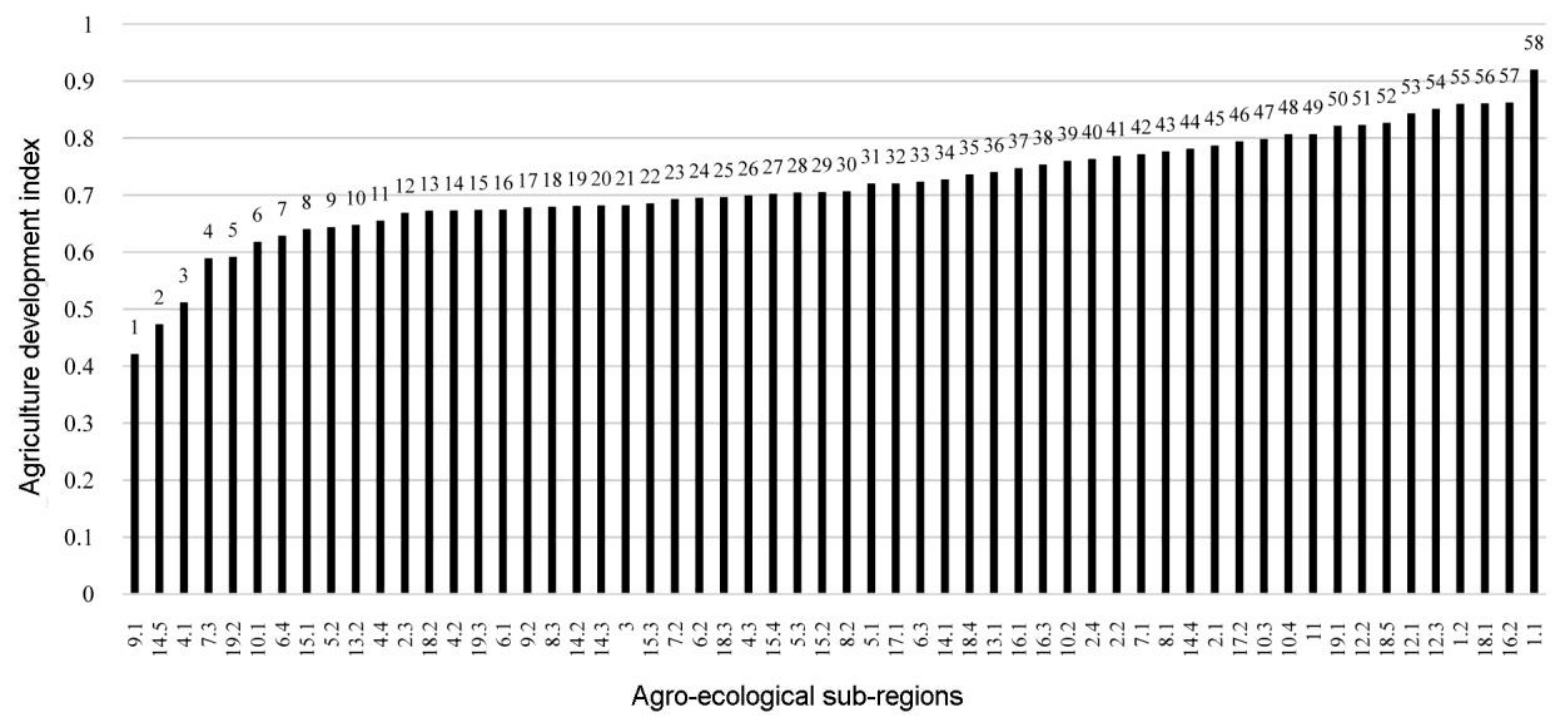

Figure 1. Ranking of assessed and mapped agro-ecological sub-regions based on agricultural development index.

Table 2. Categorization of assessed and mapped agro-ecological sub-regions (AESRs) into quartile classes and mean values of indicators of agricultural development during 2011-13

\begin{tabular}{|c|c|c|c|c|}
\hline Particulars & $\begin{array}{l}\text { High developed } \\
(0.421-0.674)\end{array}$ & $\begin{array}{l}\text { Moderate developed } \\
\quad(0.674 \text { to } 0.706)\end{array}$ & $\begin{array}{l}\text { Medium developed } \\
(0.706 \text { to } 0.781)\end{array}$ & $\begin{array}{l}\text { Less developed } \\
\qquad(>0.781)\end{array}$ \\
\hline AESR & $\begin{array}{l}2.3,4.1,4.2,4.4,5.2 \\
6.4,7.3,9.1,10.1,13.2 \\
14.5,15.1,18.2,19.2\end{array}$ & $\begin{array}{l}3,4.3,5.3,6.1,6.2,7.2,8.3 \\
9.2,14.2,14.3,15.2,15.3 \\
15.4,18.3,19.3\end{array}$ & $\begin{array}{l}2.2,2.4,5.1,6.3,7.1 \\
8.1,8.2,10.2,13.1,14.1, \\
16.1,16.3,17.1,18.4\end{array}$ & $\begin{array}{l}1.1,1.2,2.1,10.3,10.4 \\
11,12.1,12.2,12.3, \\
14.4,16.2,17.2,18.1, \\
18.5,19.1\end{array}$ \\
\hline Composite ADI & $0.602(0.021)$ & $0.689(0.003)$ & $0.744(0.005)$ & $0.830(0.01)$ \\
\hline Geographical area (m ha) & 80.4 & 90.9 & 74.4 & 81.5 \\
\hline Farmer income (Rs/year) & $95940(6976)$ & $84173(3901)$ & $83373(6897)$ & 70846 (9649) \\
\hline Crop output (Rs/ha) & $74311(6122)$ & $68980(4939)$ & $67724(13924)$ & $39600(4031)$ \\
\hline $\begin{array}{l}\text { Crop output per agricultural } \\
\text { worker (Rs/worker) }\end{array}$ & 45359 (4477) & $41136(5820)$ & $39870(7447)$ & $20224(2851)$ \\
\hline Cropping intensity (\%) & $150(5.31)$ & $138(4.82)$ & $127(4.08)$ & $124(4.3)$ \\
\hline Irrigation coverage $(\%)$ & $64(5.29)$ & $37(5.63)$ & $34(4.66)$ & $33(3.6)$ \\
\hline Groundwater development (\%) & $79.42(8.98)$ & $50(5.6)$ & $47.44(7.84)$ & $38.08(10.33)$ \\
\hline Fertilizer use (kg/ha) & $160.4(18.22)$ & $124.5(17.75)$ & $99.4(16.35)$ & $65.3(9.59)$ \\
\hline Credit use (Rs/ha) & $68371(13312)$ & $63545(13366)$ & 58717 (19219) & $43564(8364)$ \\
\hline Marketed surplus (\%) & $59.8(2.94)$ & $59.2(4.15)$ & $61.7(4.2)$ & $44.8(4.32)$ \\
\hline Access to technical advice (\%) & $22.4(3.18)$ & $24.7(4.3)$ & $15.7(2.53)$ & $11.7(2.17)$ \\
\hline
\end{tabular}

Figures within parentheses are standard errors of the estimates. ADI, Agricultural Development Index.

reforms) are appropriate strategies for improving farmers' income. Crop productivity at aggregate level can be enhanced by expanding irrigation coverage, sustainable utilization of groundwater resources, balanced use of fertilizers, raising crop intensity by bringing fallow land into cultivation, improving credit (institutional) availability and bridging the knowledge gaps ${ }^{11}$. The improved agricultural productivity would also translate into higher productivity of agricultural workers. Productivity of agricultural workers at aggregate level can be further increased by reducing the labour dependability through employment diversification towards non-farm sectors.

AESRs 1.1, 1.2, 2.1, 10.3, 10.4, 11, 12.1, 12.2, 12.3, 14.4, 16.2, 17.2, 18.1, 18.5 and 19.1 exhibited low level of agricultural development. These AESRs, covering $81.5 \mathrm{~m}$ ha geographical area, shall be prioritized and targeted for developmental efforts which would fetch quick response and lead to equitable regional development. It is pertinent to mention that each AESR (even among the less-developed ones) responds differently to the developmental activities depending upon its potential and constraints. This underscores development of customized and specific technological and policy interventions at the AESR level to achieve the target of DFI. Table 3 lists districts of the less-developed AESRs, for which a common development programme can be prepared.

Apart from agro-climatic conditions, agriculture performance is greatly influenced by various anthropogenic 
RESEARCH COMMUNICATIONS

Table 3. States and districts falling in less developed AESRs

\begin{tabular}{|c|c|c|}
\hline $\mathrm{AESR} *$ & State $^{\#}$ & District $^{\#}$ \\
\hline $1.1(5.92)$ & Jammu \& Kashmir (100) & Leh (Ladakh) (100) \\
\hline \multirow[t]{2}{*}{$1.2(9.26)$} & Himachal Pradesh (10.23) & Kinnaur (2.46), Lahul \& Spiti (7.77) \\
\hline & Jammu \& Kashmir (89.77) & Kargil (57.72), Leh (Ladakh) (32.05) \\
\hline \multirow[t]{3}{*}{$2.1(14.01)$} & Haryana (1.26) & Sirsa $(1.26)$ \\
\hline & Punjab (1.47) & Bathinda (0.04), Firozpur (0.92), Muktsar (0.5) \\
\hline & Rajasthan (97.27) & $\begin{array}{l}\text { Barmer (19.69), Bikaner (19.37), Churu (2.93), Ganganagar (8.32), Hanumangarh (4.44), } \\
\text { Jaisalmer (27.67), Jalor (0.93), Jodhpur (12.47), Nagaur (1.41), Pali (0.05) }\end{array}$ \\
\hline \multirow[t]{3}{*}{$10.3(5.67)$} & Chhattisgarh (5.65) & Bilaspur (0.82), Koriya (4.83), Mungeli (0.82) \\
\hline & Madhya Pradesh (91.14) & $\begin{array}{l}\text { Anuppur (6.19), Chhatarpur (9.86), Damoh (4.65), Dindori (6.02), Katni (4.54), } \\
\text { Panna (11.58), Rewa (3.15), Sagar (1.91), Satna (9.01), Shahdol (11.7), Sidhi (6.4), } \\
\text { Singrauli (5.7), Tikamgarh (4.55), Umaria (5.9) }\end{array}$ \\
\hline & Uttar Pradesh (3.21) & Lalitpur (3.21) \\
\hline \multirow[t]{3}{*}{$10.4(5.76)$} & Chhattisgarh (2.8) & Kawardha (2.43), Mungeli (0.15), Rajnandgaon (0.22) \\
\hline & Madhya Pradesh (70.52) & $\begin{array}{l}\text { Balaghat (15.52), Betul (2.9), Chhindwara (18.41), Dindori (5.42), Hoshangabad (0.31), } \\
\text { Jabalpur (1.31), Mandla (11.55), Narsimhapur (0.14), Seoni (14.91), Umaria (0.05) }\end{array}$ \\
\hline & Maharashtra (26.68) & $\begin{array}{l}\text { Amravati (0.86), Bhandara (6.56), Chandrapur (2.42), Gadchiroli (1.75), Gondiya (9.08), } \\
\text { Nagpur (6.01) }\end{array}$ \\
\hline \multirow[t]{6}{*}{$11(13.92)$} & Chhattisgarh (68.06) & $\begin{array}{l}\text { Bilaspur (5.54), Bastar (0.46), Dhamtari (2.85), Durg (6.18), Janjgir-Champa (2.8), Jashpur (4.22), } \\
\text { Kanker (3.26), Kawardha (2), Korba (4.8), Koriya (2.75), Mahasamund (3.25), Raigarh (4.91), } \\
\text { Raipur (8.01), Rajnandgaon (5.65), Surguja (11.38) }\end{array}$ \\
\hline & Jharkhand (18.34) & $\begin{array}{l}\text { Chatra (1.43), Garhwa (1.81), Gumla (3.59), Hazaribagh (2.08), Kodarma (0.01), Latehar (3.09), } \\
\text { Lohardaga (1.08), Palamu (1.43), Ramgarh (0.4), Ranchi (1.58), Simdega (1.84) }\end{array}$ \\
\hline & Madhya Pradesh (3.3) & Anuppur (0.19), Balaghat (0.21), Rewa (0.25), Sidhi (0.16), Singrauli (2.49) \\
\hline & Maharashtra (1.38) & Gadchiroli (1.16), Gondiya (0.22) \\
\hline & Odisha (4.83) & Bargarh (0.62), Jharsuguda (0.02), Nabarangapur (1.62), Nuapada (0.8), Sundargarh (1.76) \\
\hline & Uttar Pradesh (4.08) & Mirzapur (0.69), Sonbhadra (3.4) \\
\hline \multirow[t]{6}{*}{$12.1(17.86)$} & Andhra Pradesh (4.73) & East Godavari (2.75), Visakhapatnam (0.82), Vizianagaram (0.34), West Godavari (0.83) \\
\hline & Chhattisgarh (20.05) & $\begin{array}{l}\text { Bastar (5.43), Bijapur (4.96), Dantewada (4.9), Kanker (1.47), Mahasamund (0.15), } \\
\text { Narayanpur (2.24), Raigarh (0.12), Raipur (0.75), Rajnandgaon (0.03) }\end{array}$ \\
\hline & Jharkhand (0.42) & Pashchimi Singhbhum (0.32), Simdega (0.1) \\
\hline & Maharashtra (12.04) & Chandrapur (4.37), Gadchiroli (6.62), Yavatmal (1.06) \\
\hline & Odisha (55.67) & $\begin{array}{l}\text { Anugul (3.27), Balangir (3.65), Baleshwar (0.21), Bargarh (2.74), Baudh (1.78), Cuttack (0.57), } \\
\text { Debagarh (1.42), Dhenkanal (2.4), Gajapati (0.2), Ganjam (0.25), Jajapur (0.37), } \\
\text { Jharsuguda (1.17), Kalahandi (4.44), Kandhamal (4.39), Kendujhar(1.29), Koraput (4.74), } \\
\text { Malkangiri (3.18), Mayurbhanj (3.95), Nabarangapur (1.74), Nayagarh (0.44), Nuapada (1.54), } \\
\text { Rayagada (3.6), Sambalpur (3.78), Sonapur (1.35), Sundargarh (3.2) }\end{array}$ \\
\hline & Telangana (7.09) & Adilabad (3.03), Karimnagar (0.66), Khammam (2.81), Warangal (0.58) \\
\hline \multirow[t]{2}{*}{$12.2(3.4)$} & Andhra Pradesh (32.87) & East Godavari (3.71), Srikakulam (2.81), Visakhapatnam (19.18), Vizianagaram (7.16) \\
\hline & Odisha (67.13) & $\begin{array}{l}\text { Baleshwar (1.95), Bhadrak (3.01), Cuttack (7.43), Dhenkanal (0.67), Gajapati (9.52), } \\
\text { Ganjam (16.91), Jagatsinghapur (0.18), Jajapur (5.98), Kandhamal (0.48), Kendrapara (0.16), } \\
\text { Kendujhar (1.27), Khordha (6.25), Koraput (0.59), Malkangiri (0.26), Mayurbhanj (0.06), } \\
\text { Nayagarh (9.16), Puri (0.3), Rayagada (2.94) }\end{array}$ \\
\hline \multirow[t]{3}{*}{$12.3(7.22)$} & Jharkhand (50.86) & $\begin{array}{l}\text { Bokaro (3.96), Deoghar (0.93), Dhanbad (2.91), Dumka (3.31), Giridih (5.05), Godda (0), } \\
\text { Gumla (0.55), Hazaribagh (1.57), Jamtara (2.5), Khunti (3.3), Kodarma (0.77), Pakaur (1.15), } \\
\text { Pashchimi Singhbhum (9.19), PurbiSinghbhum (5), Ramgarh (1.19), Ranchi (4.28), } \\
\text { Sahibganj (0.06), Seraikela-kharsawan (3.71), Simdega (1.43) }\end{array}$ \\
\hline & Odisha (21.62) & $\begin{array}{l}\text { Anugul (0.73), Baleshwar (3.43), Bhadrak (1.98), Debagarh (0.46), Jajapur (0.19), } \\
\text { Kendrapara (0.14), Kendujhar (7.76), Mayurbhanj (4.74), Sundargarh }(2.19)\end{array}$ \\
\hline & West Bengal (27.51) & $\begin{array}{l}\text { Bankura (7.31), Barddhaman (2.44), Birbhum (2.7), PashimMidnapur (5.7), PurbaMidnapur (0.66), } \\
\text { Puruliya (8.7) }\end{array}$ \\
\hline \multirow[t]{3}{*}{$14.4(0.44)$} & Himachal Pradesh (16.37) & Shimla (1.97), Sirmaur (14.4) \\
\hline & Uttar Pradesh (0.44) & Saharanpur (0.44) \\
\hline & Uttarakhand (83.19) & TehriGarhwal (24.76), Uttarkashi (9.25), Dehra Dun (49.18) \\
\hline \multirow[t]{2}{*}{$16.2(1.06)$} & Sikkim $(67.53)$ & East Sikkim (8.95), North Sikkim (40.34), South (6.94), West (11.31) \\
\hline & West Bengal (32.47) & Darjiling (26.45), Jalpaiguri (6.02) \\
\hline \multirow[t]{5}{*}{$17.2(6.05)$} & Assam (4.78) & Cachar (2.39), Hailakandi (0.2), North Cachar Hills (2.18) \\
\hline & Manipur (37.82) & $\begin{array}{l}\text { Bishnupur (0.81), Chandel (5.4), Churachandpur (7.98), East Imphal (0.73), Senapati (5.91), } \\
\text { Tamenglong (7.1), Thoubal (1.21), Ukhrul (7.57), West Imphal (1.11) }\end{array}$ \\
\hline & Mizoram (35.33) & $\begin{array}{l}\text { Aizawl (3.12), Champhai (7.16), Kolasib (3.4), Lawngtlai (3.36), Lunglei (7.6), Mamit (5.04), } \\
\text { Saiha (3.31), Serchhip (2.33) }\end{array}$ \\
\hline & Nagaland (5.97) & Dimapur (0.04), Kiphire (0.14), Kohima (0.81), Peren (2.31), Phek (2.67) \\
\hline & Tripura $(16.11)$ & Dhalai (3.72), Gomati (6.07), Khowal (4.28), North Tripura (2.04) \\
\hline
\end{tabular}




\section{RESEARCH COMMUNICATIONS}

Table 3. (Contd)

\begin{tabular}{lll}
\hline AESR* & \multicolumn{1}{c}{ State $^{\#}$} & \\
\hline $18.1(0.14)$ & Tamil Nadu (100) & District $^{\#}$ \\
$18.5(0.01)$ & Odisha (100) & Ramanathapuram (46.92), Thoothukkudi (53.08) \\
$19.1(2.45)$ & Dadra \& Nagar Haveli (2.03) & Jagatsinghapur (86.36), Kendrapara (9.85), Puri (3.79) \\
& Daman \& Diu (0.3) & Daman (0.3) \\
& Gujarat (34.02) & Bhavnagar (0.39), Navsari (9.11), Surat (6.48), Tapi (1.55), The Dangs (4.15), Valsad (12.35) \\
& Maharashtra (63.64) & Nashik (7.33), Pune (6.69), Raygad (13.79), Thane (35.84) \\
\hline
\end{tabular}

Note: *Figures in parentheses are total area of AESR (m ha).

"Figures in parentheses are the share of a state's/district's geographical area in the respective AESRs.

Districts in bold are potential districts of the respective AESRs.

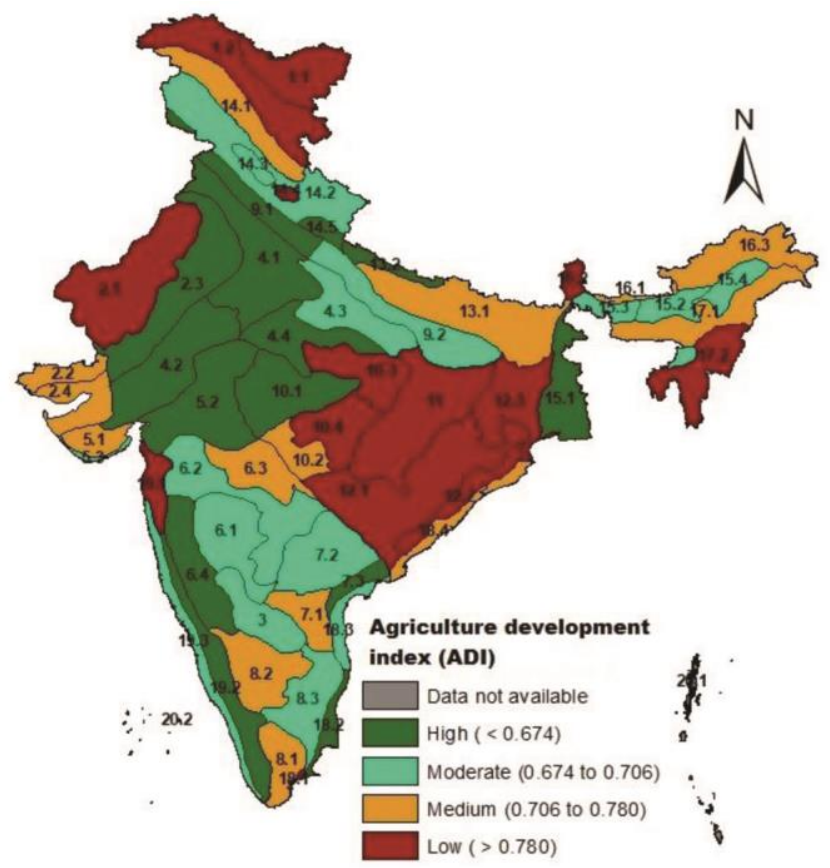

Figure 2. Categorization of AESRs based on agriculture development.

factors prevailing at sub-regional level. The present study has examined the variation in agricultural development among the districts falling within each AESR. For this, ADI of the ten selected indicators was estimated for 576 districts and these districts were classified into four quartile classes representing high, moderate, medium and low levels of agricultural development. Subsequently, ADI map of districts was superimposed on AESR map to reflect the variation in agricultural development within AESRs (Figure 3). The results reveal wide variation in agricultural development at sub-regional level in all the AESRs, except a few. The overall level of agricultural development in a given AESR would be a combined measure (weighted average) of agricultural development in districts falling within its boundary. Thus, a lessdeveloped AESR might have district(s) with a high level of agricultural development and vice-versa. As all districts falling in a given AESR exhibit similar agro-

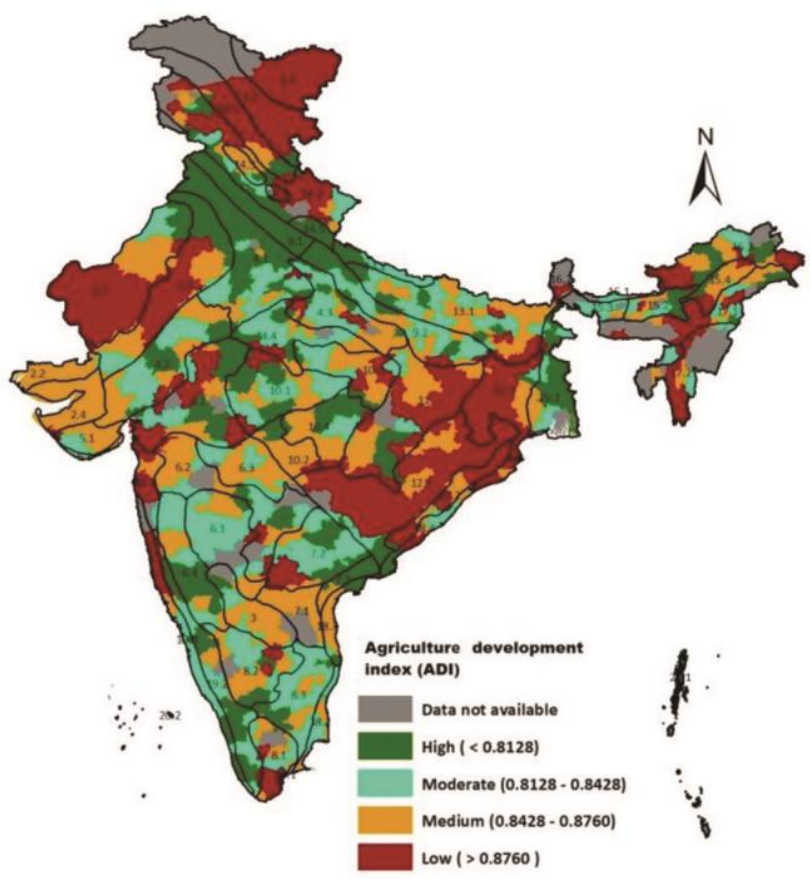

Figure 3. Intra-AESR variation in level of agricultural development.

climatic conditions, districts with a high level of development, particularly in a less-developed AESR, can be identified as potential districts for that region. Such potential districts for less-developed AESR have been identified and listed in Table 3 (boldface). Similarly, districts with low-level of agricultural development falling in highly-developed AESRs can be targeted for developmental activities.

ADI-based mapping of AESRs assumes a crucial role in achieving the target of DFI in India. It helps developmental planners identify and prioritize agriculturally lessdeveloped regions, and formulate customized strategic plans that would fetch near uniform response to the interventions at AESR level. Outcomes of the efforts targeted towards less-developed regions are expected to be large and equitable. The present study has evaluated these hypotheses while drawing the implications of ADI-based mapping on DFI in the country. The analysis includes 
RESEARCH COMMUNICATIONS

Table 4. Effect of targeting a region on overall farmers' income in India

\begin{tabular}{|c|c|c|c|c|}
\hline Particulars & $\begin{array}{l}\text { Highly developed } \\
\text { regions }\end{array}$ & $\begin{array}{l}\text { Moderately developed } \\
\quad \text { regions }\end{array}$ & $\begin{array}{l}\text { Medium developed } \\
\text { regions }\end{array}$ & $\begin{array}{l}\text { Less developed } \\
\text { regions }\end{array}$ \\
\hline Geographical area (m ha) & 80.4 & 90.9 & 74.4 & 81.5 \\
\hline Mean farmers' income (Rs/farmer household) & 95,940 & 84,173 & 83,373 & 70846 \\
\hline Share in total farmers' income $(\%)$ & 28.2 & 28.0 & 22.7 & 21.1 \\
\hline Standard error of farmers' income & 6976 & 3901 & 6897 & 9649 \\
\hline Attainable income (Rs/farmer household) & 116,868 & 95,876 & 104,064 & 99,793 \\
\hline Gap between actual and attainable income (\%) & 21.8 & 13.9 & 24.8 & 40.9 \\
\hline $\begin{array}{l}\text { Marginal effect on targeting a region on total } \\
\text { farmers' income }(\%)\end{array}$ & 6.15 & 3.89 & 5.63 & 8.63 \\
\hline
\end{tabular}

obtaining attainable level of income for each region and simulating marginal effect of achieving that level in a given region on overall farmers' income in the country. For simplicity, mean farmers' income plus three-standard error, which represents the upper limit in a normally distributed population at $99 \%$ confidence interval, has been taken as a proxy measure for attainable income (Table 4). The less-developed regions exhibited the highest variability in mean income level with $40.9 \%$ gap between actual and attainable income. The results reveal that if agriculturally less-developed regions fill this gap, farmers' income in the nation would increase by $8.63 \%$. On the other hand, marginal effect of targeting high, medium and moderately developed regions on overall farmers' income would be $6.15 \%, 5.63 \%$ and $3.89 \%$ respectively. Further, targeting less-developed regions would lead to faster reduction in inter-regional disparity in the income. The CV value among the four regions at the present level of farmers' income was estimated as $12 \%$. In the scenario of targeting highly-developed regions, ceteris paribus, the CV value increased to $22 \%$. However, targeting less-developed regions resulted in reduction in $\mathrm{CV}$ value to $9 \%$. These results suggest large and equitable outcomes of targeting agriculturally less-developed regions.

There exists wide regional variation in the level of agricultural development depending upon the potential and constraints in the respective AESR. The characterization and mapping of AESRs significantly contribute in agricultural planning and developmental activities through delineating regions with varying levels of agricultural development. It is expected that a given intervention would produce almost similar response within an AESR. Therefore, the present study advocates customized technological and policy interventions at the AESR level to achieve the target of DFI within the stipulated time-frame. For effective implementation and monitoring of interventions, districts falling in each of the less-developed AESRs have been identified. Further, potential districts for each of the less-developed AESRs have also been identified, which can be taken as a benchmark for evaluating the progress of developmental activities. The study concludes that prioritization and targeting of agriculturally less-developed regions would fetch large and equitable response of the interventions aimed towards DFI.
1. Chand, R., Doubling Farmers' Income: Rationale, Strategy, Prospects and Action Plan. NITI Policy Paper 01/2017, New Delhi, NITI Aayog, Government of India, 2017.

2. MoA\&FW, Status of Farmers' Income: Strategies for Accelerated Growth. Report of the Committee on Doubling Farmers' Income (Volume II), Department of Agriculture, Cooperation and Farmers' Welfare, Ministry of Agriculture \& Farmers' Welfare, 2017.

3. Krishnan, A. and Singh, M., Soil climatic zones in relation to cropping patterns. In Proceedings of the Symposium on Cropping Patterns, Indian Council of Agricultural Research, New Delhi, 1968, pp. 172-185.

4. Murthy, R. S. and Pandey, S., Delineations of agro-ecological regions of India. In Paper presented in Commission V, 11th Congress of Inter-departmental Science Students' Society, Edmonton, Canada, 19-27 June 1978.

5. Planning Commission of India, Agro-climatic Zones of India, Annual Report, 1989-90, Government of India, pp. 39-40.

6. Sehgal, J., Mandal, D. K., Mandal, C., Vadivelu, S., Agroecological regions of India 2nd edn, NBSS\&LUP, Publ. No. 24, ICAR-National Bureau of Soil Survey and Land Use Planning, Nagpur, 1992, p. 130.

7. Mandal, C., Mandal, D. K., Bhattacharyya, T., Sarkar, D. and Pal, D. K., Revisiting agro-ecological sub regions of India - a case study of two major food production zones. Curr. Sci., 2014, 107(9), 1519-1536.

8. Bhattacharyya, T., Mandal, C., Mandal, D. K., Prasad, J., Tiwari, P., Venugopalan, M. V. and Pal, D. K., Agro-eco sub-region-based crop planning in the black soil regions and Indo-Gangetic plainsapplication of soil information system. Proc. Indian Natl. Sci. Acad., 2015, 81(5), 1151-1170.

9. Planning Commission, Report of the Working Group on Agricultural Research and Education for the Tenth Five Year Plan. Planning Commission, Government of India, 2001.

10. Bhatia, V. K. and Rai. S. C., Evaluation of socio-economic development in small areas. Project report, Indian Society of Agricultural Statistics. IASRI campus, New Delhi, 2004.

11. Srivastava S. K., Ghosh, S., Kumar, A. and. Anand, P. S. B., Unravelling spatio-temporal pattern of irrigation development and its impact on Indian agriculture. Irrigation Drainage, 2014, 63(1), $1-11$.

ACKNOWLEDGEMENTS. This research is part of the extra-mural project 'identifying pathways of socio-economic and socio-personal attributes and study their influence on agricultural performance across different Agro-ecosystems in India' funded by Indian Council of Agricultural Research, New Delhi.

Received 12 April 2018; revised accepted 27 March 2019

doi: $10.18520 / \mathrm{cs} / \mathrm{v} 117 / \mathrm{i} 2 / 282-287$ 